65.ブラインド制御用直身白炎検出センサ

岩淵邦彦 坪田祐二 牧 悦子 笹井敏彦 清水恵一

（東京電力株式会社）（東芝ライテック株式会社）

\title{
1.はじめに
}

ブラインドを用いた昼光利用照明制御システムは、室内の光環境を維持しつつ照明用電力量の削減 をはかるシステムとして実用化されている。しかし、ブラインド制御のためのセンサは昼光から天空 光成分を除去した直射日光成分のみを検出する必要があるため、可動部を有し大脚かりであった。シ ステムの普及を図るため可動部がなく、小形で低照度域まで直射日光を検出可能な直射日光検出セン サの検討したので報告する。

\section{2. センサの構造}

直射日光を検出するためにスリットと複数の受 光素子（フォトダイオードアレイを使用）を用い て天空を分割し、太陽位置（方位角、高度）デー 夕に対応する受光素子を選択することにより、セ ンサに入射する不要な天空光による成分の低減を 図った。図 1 にセンサの概略構造を示す。前面士 $90^{\circ}$ をカバーするため、フォトダイオードアレ イ 2 個を $90^{\circ}$ の角度をなすように配置した。素 子の選択はパーソナルコンピュータにより制御し 同時に法線方向の照度への変換を行った。

\section{3. 結果}

試作したセンサの基本仕様を表 1 に法線方向の 照度に変換した検出量と直射日光法線照度との相 関を図 2 に示す。低照度域で若干大き目の值を示 すが広いレンジにわたり直射日光法線照度との相 関を保っている。ブラインドの開閉は直射日光法 線照度 $100000 \quad\left[\begin{array}{lll}1 & 0\end{array}\right]$ 前後を境に行うがそれ以 下の照度まで相関を保ち、実用上十分な特性であ る事がわかった。

表. 1 センサ基本仕様

\begin{tabular}{|l|l|}
\hline 出力電圧 & $0 \sim 10 \mathrm{~V}$ \\
\hline 検出照度変換係数 & $1 \mathrm{~V} / 100001 \mathrm{x}$ \\
\hline 検出素子 & $\begin{array}{l}35 \text { 素子シリコンフォトダイオード } \\
\text { アレイ (2 個使用) }\end{array}$ \\
\hline 検知エリア & 水平 $190^{\circ}$ 垂直 73. $5^{\circ}$ \\
\hline $\begin{array}{l}\text { 直射日光法線照度算 } \\
\text { 出方浍出值と太陽位置により直射日光 } \\
\text { 法線照度を算出 }\end{array}$ \\
\hline
\end{tabular}

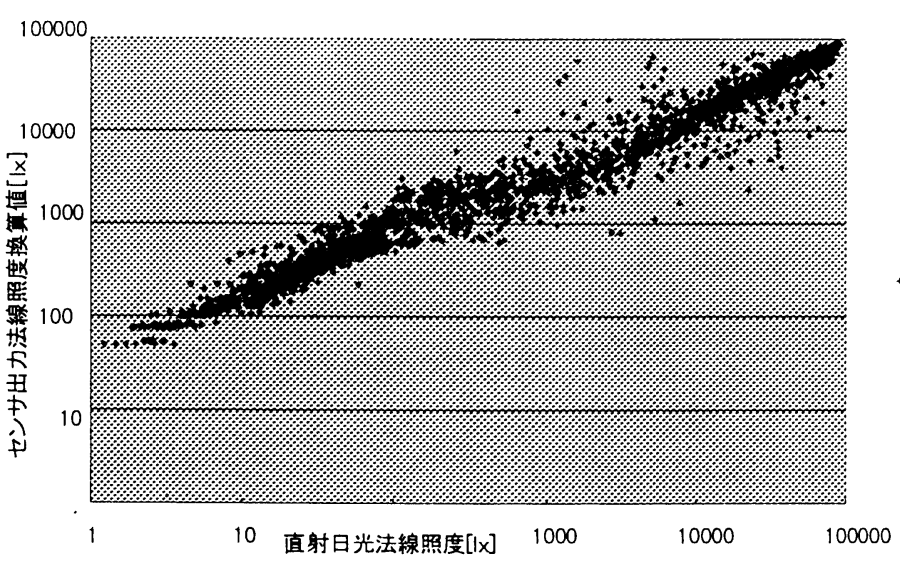

図 2. センサの特性

\section{4. まとめ}

低照度域まで検出可能な小形で可動部のない方式のセンサを検討した。ブラインドと窓の間に設置 可能であり、防水構造等を必要としない簡易型センサとして有用と考えられる。

\section{参考文献}

仲田、井上他 : 東京電力（株）技術開発センターにおける照明制御システムの効果(照学全大 1996 年)

Direct sunlight sensor for blind control

Kunihiko Iwabuchi, Yuji Tsubota, Etsuko Maki, Toshihiko Sasai, Keiichi Shimizu 